\title{
Research Article \\ Effect of Gradient Nanostructured Ti on Behaviours of MG63 Cells In Vitro
}

\author{
Xue Luo, ${ }^{1}$ Chen Liang, ${ }^{2}$ Ning Li, ${ }^{3}$ Yuhe Zhu, ${ }^{1}$ Nanjue Cao $\left(D,{ }^{4}\right.$ Jin Wang, ${ }^{1}$ Keda Liu $\left(\mathbb{D},{ }^{1}\right.$ \\ Hongwei Zhao $\mathbb{D}^{3}{ }^{3}$ Zhenbo Wang $\mathbb{D}^{2}$, and Wei Wang ${ }^{1}$ \\ ${ }^{1}$ School and Hospital of Stomatology, China Medical University, Liaoning Provincial Key Laboratory of Oral Diseases, \\ Shenyang 110001, China \\ ${ }^{2}$ Shenyang National Laboratory for Materials Science, Institute of Metal Research, Chinese Academy Sciences, \\ Shenyang 110016, China \\ ${ }^{3}$ Department of Orthopedics, The Fourth Central Hospital of Baoding City, Baoding 072350, China \\ ${ }^{4}$ The Fourth Affiliated Hospital, Zhejiang University School of Medicine, Yiwu 322000, China
}

Correspondence should be addressed to Hongwei Zhao; 13931386052@163.com, Zhenbo Wang; zbwang@imr.ac.cn, and Wei Wang; wwang75@cmu.edu.cn

Received 6 April 2020; Accepted 24 April 2020; Published 5 June 2020

Academic Editor: Hui-Qi Xie

Copyright ( 2020 Xue Luo et al. This is an open access article distributed under the Creative Commons Attribution License, which permits unrestricted use, distribution, and reproduction in any medium, provided the original work is properly cited.

\begin{abstract}
Titanium (Ti) is widely used in oral implants. However, there is still a challenge to promote the osseointegration of bone tissue on the surface of Ti. To solve this problem, we prepared novel gradient nanostructured (GNS) Ti and studied the effect of GNS on the adhesion, proliferation, and apoptosis of MG63 cells in vitro. The results demonstrated that the GNS Ti promoted the adhesion effect and proliferation of MG63 cells better than the annealed Ti, while the ability of GNS Ti to inhibit cell apoptosis was better than that of the annealed $\mathrm{Ti}$, the preliminary mechanism of which indicated by this study might be the enhanced mineralization capacity, protein adsorption ability, and hydrophilicity of the GNS Ti due to its specific nanostructure which improved the cell behaviours. The results in this study provide the theoretical and experimental foundations for the applications of GNS Ti in dental implants and joint replacements.
\end{abstract}

\section{Introduction}

Titanium (Ti) is widely used in oral implants due to its nontoxicity, lightweight, high specific strength, corrosion resistance, and fatigue resistance [1-3]. However, $\mathrm{Ti}$ is a biologically inert material [4-6], which tends to form fibrous bonds with bone tissue instead of osseointegration [7-11].

To improve the combination between Ti to bone tissue, a large number of researchers have used surface modification methods to enhance the bonding strength between $\mathrm{Ti}$ and bone tissue [12]. Especially, nanostructured surface could hopefully bring desired effects on behaviours of surrounding cells, thereby promoting bone formation [13]. Chen et al. reported that nano-scale $\mathrm{Ti}$ materials demonstrated better biocompatibility than micron-scale and millimeter-scale counterparts, and that the ability of the nano-scale Ti materials to improve osteogenic differentiation of bone marrow mesenchymal stem cells was significantly better than that of the control groups [14]. Yang et al. cultured MC-3T3 cells on micro-scale and nano-scale silicon structures with different surface modifications and found that the silicon scaffolds with nanostructure had better ability to promote MC-3T3 cells proliferation and adhesion than those with coarse structure [15]. The study of Huang et al. demonstrated that their prepared nanostructured Ti-25Nb-3Mo-3Zr-2Sn (TLM) could support the adhesion and proliferation of hFOB1.19 cells better than their prepared microstructured TLM [16]. Moreover, Li et al. found that the compacts made of carbon nanotubes could promote osteogenic differentiation of human adipose-derived MSCs in vitro and bone formation 
in vivo, while graphite compacts with the same component and dimension could not [17]. Therefore, the construction of nanostructures on Ti surface may be one of the effective methods to improve its osseointegration.

Surface mechanical attrition treatment (SMAT) is a potential physical modification method to obtain novel gradient nanostructured surface (GNS) Ti materials. The principle involves the use of steel balls to impact metal-based materials at high speed with indefinite impact direction under the action of ultrasonic waves, by which the surface of the material undergoes strong plastic deformation, gradually refined to nano-scale [18-25]. The surface of GNS is nano-scale and gradually increased to the micron levels as the distance from the surface increases.

In this study, the GNS Ti samples were prepared by SMAT, and annealed Ti samples were obtained by recrystallization annealing, making sure that the two kinds of specimens had similar roughness. Then, MG63 cells were cocultured with the two kinds of different structured Ti to investigate the material structure effects on the cellular behaviours. The effects of material structure changes on surface properties including mineralization capacity, protein adsorption capacity, and hydrophilicity were also comparatively investigated. This study aimed at elucidating the effects of GNS Ti on adhesion, proliferation, and apoptosis of the cells and clarifying the preliminary mechanism, providing a theoretical basis for the application of GNS Ti as a new dental implant or joint replacement material.

\section{Materials and Methods}

2.1. Preparation of Materials. The Ti plates were put into ultrasonic-assisted SMAT to produce GNS Ti, as described in previous work. Briefly, repeated plastic deformation under high strains and strain rates was produced within the surface layer of samples using a large number of hardened steel (AISI 52100 ) balls, which were vibrated in a chamber driven by an ultrasonic generator. Consequently, grains in the surface layer were effectively refined on the nano-scale, and a depth-dependent microstructure was generated. In this study, the SMAT process was performed for $20 \mathrm{~min}$ at a driving frequency of $20 \mathrm{kHz}$.

The controlled group was prepared by the SMAT procedure and followed by a recrystallization annealing process at $680^{\circ} \mathrm{C}$ for $2 \mathrm{~h}$, so that the grain size was grown. The surface roughness values of the experimental group and controlled group were similar.

The GNS Ti and the annealed Ti were cut into cylindrical Ti pieces with a diameter of $11 \mathrm{~mm}$ and a thickness of $2.5 \mathrm{~mm}$ by using the electrospark discharge method. After being pickled in a $2 \mathrm{M} \mathrm{HCl}$ aqueous solution to remove any possible contamination, the samples were subsequently cleaned in acetone, absolute alcohol, and distilled water under ambient conditions and finally dried in air before testing.

2.2. Surface Structures and Roughness. The longitudinal sectional morphology was observed using an FEI Nova Nano SEM 430 scanning electronic microscope (SEM) operated at a voltage of $15 \mathrm{kV}$. Meanwhile, the samples were mechani- cally ground and polished and then etched in an electrolyte of perchloric acid, butyl alcohol, and methanol with the ratio $1: 6: 10$ (in volume). Detailed microstructural characterization of the SMAT surface was conducted using transmission electron microscopy (TEM) with a JEOL-2010 unit operated at $200 \mathrm{kV}$. TEM thin foils were cut using the electrospark discharge technique, mechanically polished, dimpled, and finally ion milled from the untreated side. The surface roughness values of the different samples were observed using an Olympus LEXT OLS4000 confocal laser scanning microscope.

2.3. Culture of MG63 Cells. MG63 cells were provided by the Stem Cell and Regenerative Medicine Laboratory of China Medical University. MG63 cells were cultured in a highglucose medium containing $10 \%$ fetal bovine serum and $0.2 \%$ gentamicin at $37^{\circ} \mathrm{C}$ with a humidified incubator containing $5 \% \mathrm{CO}_{2}$.

2.4. SEM Observation. After 1 day of culture, the two groups of materials were transferred to a new 24-well plate and washed three times with PBS for 5 min each. Then, the samples were fixed by $2.5 \%(W / W)$ buffered glutaraldehyde in $4^{\circ} \mathrm{C}$ refrigerator for more than $4 \mathrm{~h}$ and washed three times with PBS for $5 \mathrm{~min}$ each. Finally, the samples were dehydrated by gradient concentrations (15\%, 30\%, 45\%, 60\%, $75 \%, 90 \%$, and $100 \%$ ) of ethanol for 10 minutes each time and dried overnight. The adhesion and morphology of the cells were observed with a Hitachi S-3- 400 SEM operated at a voltage of $15 \mathrm{kV}$.

2.5. MTS Analysis of Cell Proliferation. The proliferation behaviour of MG63 cells was analyzed using optical density (OD) absorbance measurements. MG63 cells were seeded at $2 \times 10^{4}$ cells $/ \mathrm{cm}^{2}$ into two groups of materials and blank plates, and each well was made up with $2 \mathrm{ml}$ of culture medium. Each group of materials was paved with 3 holes. After 1, 3, 5, and 7 days of culture, each group of materials was transferred to a new 24-well plate and rinsed twice with PBS. The samples were further cultured for $2 \mathrm{~h}$ in culture medium added with MTS. The optical density (OD) value of each well was measured by using an Infinite M200 microplate reader (Tecan Company, Switzerland) at a wavelength of $450 \mathrm{~nm}$.

2.6. Flow Cytometric Analysis of Cell Apoptosis. The two groups of materials were immersed in DMEM culture medium at a ratio of $1 \mathrm{ml}$ DMEM culture medium per $3 \mathrm{~cm}^{2}$ and placed them in a $37^{\circ} \mathrm{C}$ incubator for $72 \mathrm{~h}$. Effect of materials on cell apoptosis was studied using an Annexin V-FITC cell apoptosis detection kit from Solarbio (Beijing, China). The cells were seeded in new 24 -well plates at a density of $1 \times 10^{6}$ cells/well. After $24 \mathrm{~h}$ of culture, the culture medium was replaced by the GNS Ti and annealed Ti extraction medium and incubated in $5 \% \mathrm{CO}_{2}$ at $37^{\circ} \mathrm{C}$ for $48 \mathrm{~h}$. Cells cultured in the absence of samples were used as the negative control. The cells were collected by centrifugation and washed twice with PBS. Cell pellets were resuspended in $195 \mathrm{ml}$ of Annexin V-FITC binding buffer. After the addition of $5 \mathrm{ml}$ of Annexin V-FITC and $10 \mathrm{ml}$ of propidium 
iodide (PI), cells were incubated at room temperature for 15 minutes and subjected to analysis on a flow cytometer (Beckman Coulter, USA).

2.7. Biomimetic Mineralization Experiment. The GNS Ti and annealed $\mathrm{Ti}$ were placed vertically into six-well plates and immersed in simulated body fluid (SBF). The SBF was changed every two days. The samples were cultured in a constant temperature incubator $\left(37^{\circ} \mathrm{C}\right)$ for 28 days. SEM was used to observe the change of surface morphology. Energydispersive X-ray spectroscopy (EDX, Hitachi, Japan) was used to detect the composition of surface deposits.

2.8. Protein Adsorption Experiment. The two groups of samples after sterilization were placed in 24 -well plates with the treatment surface facing up. Each sample was added culture medium containing $10 \%$ fetal bovine serum and incubated at a $37^{\circ} \mathrm{C}$ incubator for 1,4 , and 24 hours. Then, the samples were transferred to new 24-well plates and gently rinsed 3 times with $1 \mathrm{ml}$ phosphate buffer solution (PBS). One percent $(W / V)$ of sodium dodecyl sulfate (SDS) was added to each well. The samples were shaken on a shaker at $70 \mathrm{r} / \mathrm{min}$ for $30 \mathrm{~min}$ to elute the protein adsorbed on the surface of the samples. The total protein concentration collected in the SDS solution was measured by a microplate reader at a wavelength of $562 \mathrm{~nm}$.

2.9. Hydrophilic Experiment. The hydrophilicity of GNS Ti and annealed Ti was studied by measuring the contact angles with deionized water and materials by using a contact angle measuring instrument (German DataPhysics Company). Three parallel samples were set in the experiment. Different areas of each sample was tested three times with deionized water. The average value was used as the corresponding index test value to ensure the reliability of the experimental results.

2.10. Statistical Analysis. All results were generated in three independent experiments with three repeats. The results were processed by the SPSS17.0 software and expressed as mean \pm standard deviation (standard error). One-way ANOVA was used to compare the OD value and protein adsorption between the groups. The comparison between groups was performed by the LSD $t$ test. The difference was statistically significant at $P<0.05$.

\section{Results}

3.1. Surface Structure and Roughness of the GNS Ti and the Annealed $\mathrm{Ti}$. In this study, the samples were characterized by SEM, TEM, and confocal laser scanning microscopy, respectively. Evidence of plastic deformation, microstructure refinement, and the differences in surface roughness between the materials were clearly observed in Figure 1. As shown in Figures 1(a) and 1(b), the longitudinal section image of GNS Ti samples displayed a gradient change that the grain size gradually decreased from the sample interior to the treated surface, accompanied by gradually intensifying plastic deformation. The microstructure in the top surface layer could not be clearly observed in the SEM image due to the extremely small grain size and intensive deformation. In comparison, no gradient microstructural characterization could be found in annealed Ti samples. As shown in Figure 1(c), TEM observation revealed that the grains in the top surface layer of the GNS Ti samples were refined into nanometer scale with random crystallographic orientations. The difference of surface morphology was further demonstrated by the $3 \mathrm{D}$ isoheight images captured by the confocal laser scanning microscopy and quantified with surface roughness parameters, as shown in Figures 1(d) and 1(e). The surface roughness $\left(R_{\mathrm{a}}\right)$ values of the GNS $\mathrm{Ti}$ and annealed $\mathrm{Ti}$ samples were $1.76 \pm 0.13 \mu \mathrm{m}$ and $1.84 \pm 0.09 \mu \mathrm{m}$, respectively. After statistical analysis, there was no statistical difference in surface roughness between two groups of materials $(P>0.05)$. The effect of material surface roughness on the cellular behaviours was ruled out.

3.2. Behaviours of MG63 Cells on the GNS Ti Samples and the Annealed Ti Samples. As shown in Figures 2(a)-2(f), the morphology of MG63 cells cultured on the two kinds of materials for 1 day was presented. The MG63 cells were observed to spread homogenously and fully on the surface of GNS Ti samples. Meanwhile, the MG63 cells were predominantly in the shape of polygon, reaching out plentiful filopodia to touch the surface of samples or connecting neighboring cells. In contrast, the number of MG63 cells that adhered to the annealed Ti was less than that on the GNS Ti. MG63 cells were usually isolated on the surface of annealed Ti, having fewer pseudopods protruding.

Typically, OD absorbance values of samples cultured for different times were measured to evaluate the proliferation kinetics of MG63 cells. MG63 cells were cocultured with GNS Ti and annealed Ti for 1, 3, 5, and 7 days. As shown in Figure 2(g), MG63 cells proliferated well on the GNS Ti surface within the entire culturing time, suggesting good biocompatibility of the GNS Ti group. There was no difference in the number of MG63 cells at 1 day between the two groups, while the GNS Ti group showed significantly higher OD values at 3,5 , and 7 days $(P<0.05)$, implying MG63 cells displayed better proliferation capacity on the GNS Ti. Slopes of the two group of samples are as follows: from day 1 to day 3: $0.13185 \pm 0.03035$ vs. $0.08835 \pm 0.03515, P<0.05$; from day 3 to day 5: $0.05995 \pm 0.0018$ vs. $0.0338 \pm$ $0.00885, P<0.05$; and from day 5 to day $7: 0.0657 \pm$ 0.01395 vs. $0.04915 \pm 0.00335, P<0.05$. After statistical analysis, the slopes of samples were statistically different on the $3 \mathrm{rd}$, 5th, and 7 th days $(P<0.05)$.

The scatter plot of cell suspensions was observed to reveal the results of cell apoptosis, as shown in Figures 2(h)-2(j). The blank control group and the GNS Ti group were concentrated a large number of live cells in the lower left quadrant, and the late apoptotic cells of the GNS Ti group were significantly more than the blank control group. Numerous advanced apoptotic and necrotic cells were identified in the right upper quadrant of the annealed $\mathrm{Ti}$ group. Table 1 showed that no significant differences among the contents of the early apoptotic cells, late apoptotic cells, and necrotic cells were found between the blank control group and the GNS Ti group. However, these three types of cells in the 


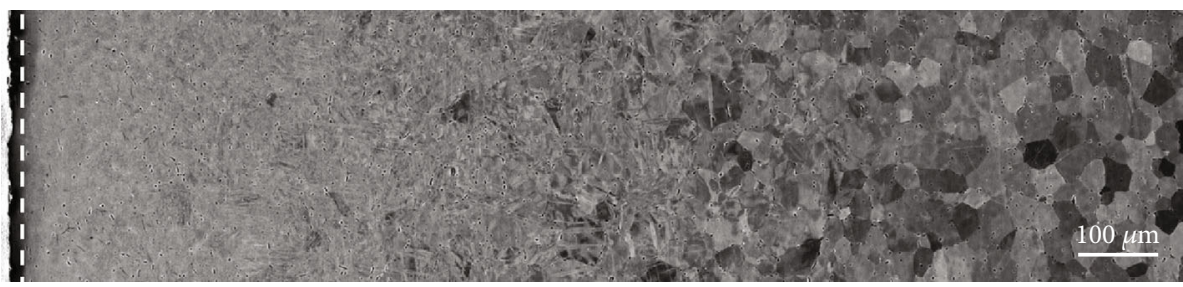

(a)

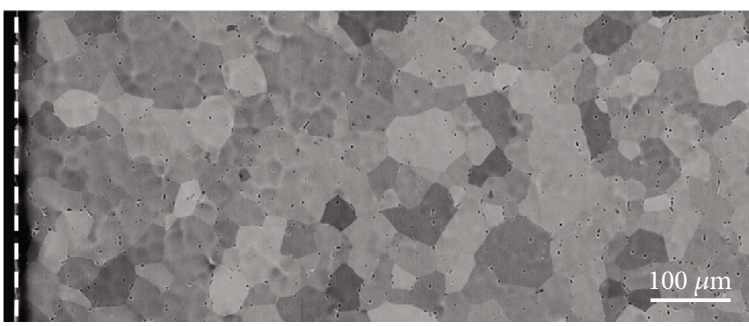

(b)

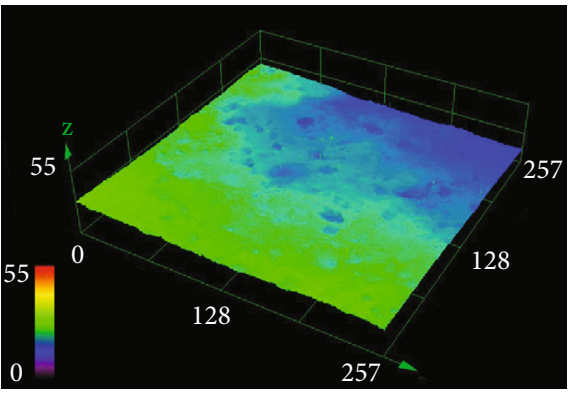

(d)

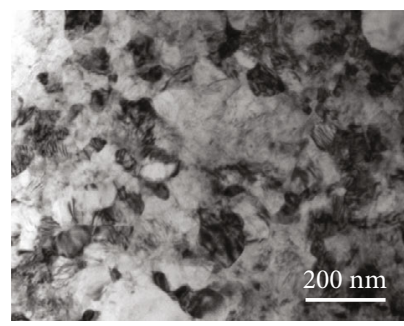

(c)

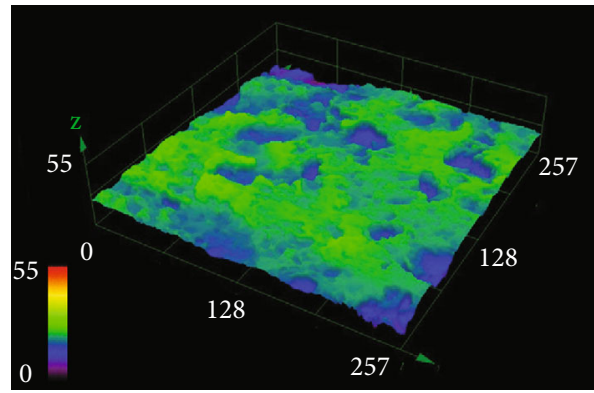

(e)

Figure 1: $(a, b)$ Longitudinal section SEM images of the GNS Ti samples and the annealed Ti samples. The dashed lines mark the treated surfaces before and after annealing. (c) Typical bright-field TEM images of the top surface layer of the GNS Ti samples. (d, e) 3D isoheight images show the surface roughness values of the GNS Ti samples and the annealed Ti samples.

annealed Ti group were larger in number than those in the blank control group $(P<0.05)$. The early apoptotic cells, late apoptotic cells, and necrotic cells in the group were higher than those in the GNS Ti group $(P<0.05)$.

3.3. Surface Properties of the GNS Ti Samples and the Annealed Ti Samples. To compare the biomineralization ability, the samples were immersed in SBF for 28 days. From Figures 3(a)-3(d), it could be seen that the surface of GNS $\mathrm{Ti}$ induced the formation of new compounds and formed a spherical coating after 28 days of SBF incubation. The surface of annealed $\mathrm{Ti}$ was snow-like coating that did not induce the formation of new compounds. Furthermore, the EDX analysis showed that these new compounds on the GNS Ti surface (Figures 3(e) and 3(f)) mainly contained calcium and phosphorus.

The difference in surface properties of the GNS Ti and annealed $\mathrm{Ti}$ was reflected by measuring the total protein adsorption of the two groups of samples. The total protein adsorbed on the GNS Ti and annealed Ti surfaces from cell culture medium containing fetal bovine serum after 1, 4, and $24 \mathrm{~h}$ of incubation are displayed in Table 2 and Figure $3(\mathrm{~g})$. At each incubation time, the GNS Ti significantly promoted the adsorption amounts of total protein compared to annealed Ti. After statistical analysis, the protein adsorption results between the two groups were statistically different on the 1 st, 4 th, and 24 th hours $(P<0.05)$. Especially, the amount of protein adsorption of the GNS Ti increased rapidly during 4 hours compared with that of the annealed Ti. Overall, the GNS Ti completed the protein adsorption on the surface in a comparatively short time.

Water droplet contact angle measurements were used to test the surface hydrophilicity of the GNS $\mathrm{Ti}$ and the annealed $\mathrm{Ti}$ (Figures 3(h) and 3(i)). The contact angle of the GNS Ti surface was significantly smaller than that of the control surface $\left(53.7^{\circ} \pm 2.4^{\circ}\right.$ vs. $\left.96.9^{\circ} \pm 3.8^{\circ}, P<0.05\right)$, suggesting relatively better hydrophilicity of GNS $\mathrm{Ti}$ surfaces, which might come from the specific nanostructure of GNS Ti.

\section{Discussion}

In this study, to improve the osseointegration ability of $\mathrm{Ti}$, we prepared GNS Ti samples by SMAT. The annealed Ti samples were used as control. It was shown by SEM that the average grain size of GNS Ti was nano-scale on the uppermost surface and gradually increased to submicron and micron levels as the distance from the surface increases. In comparison, no such nanostructural characterization could be found 


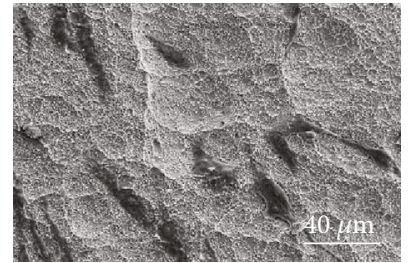

(a)

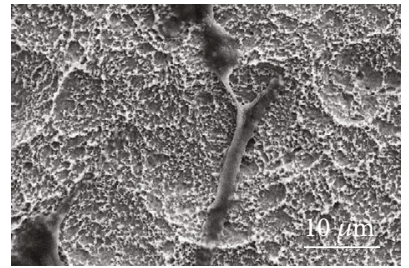

(d)

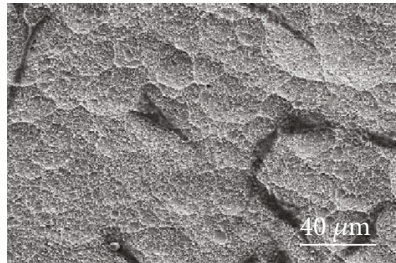

(b)

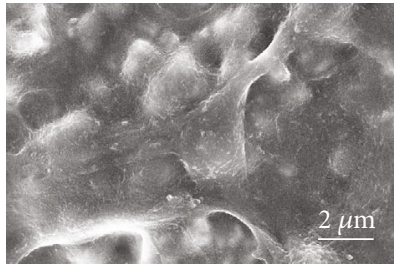

(e)

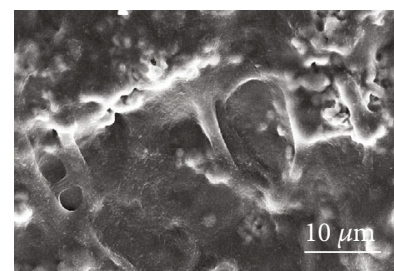

(c)

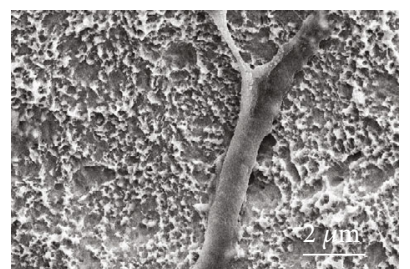

(f)
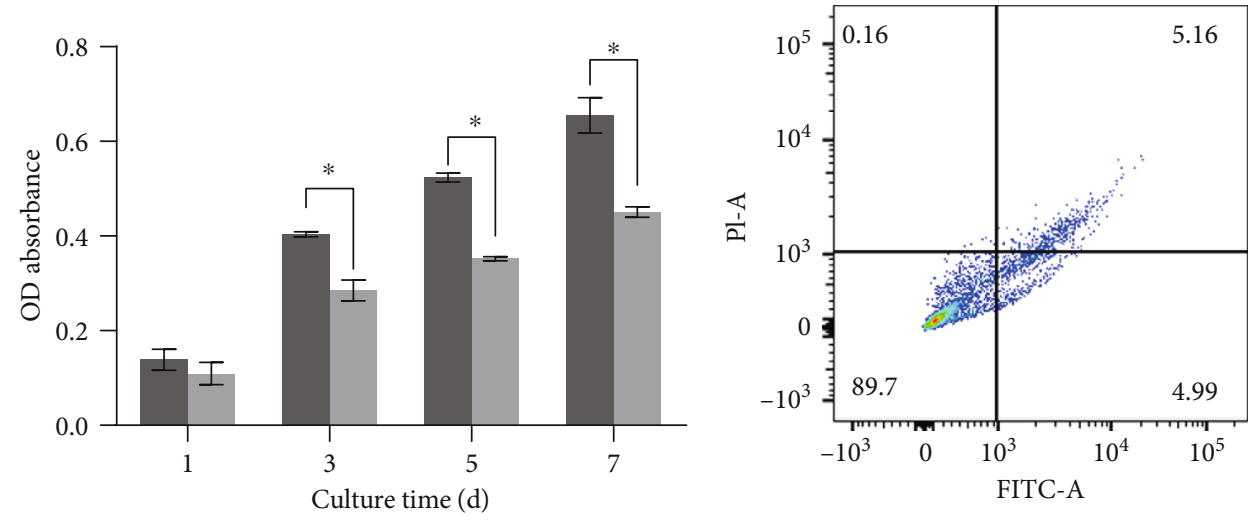

GNS Ti

Annealed Ti

(g)

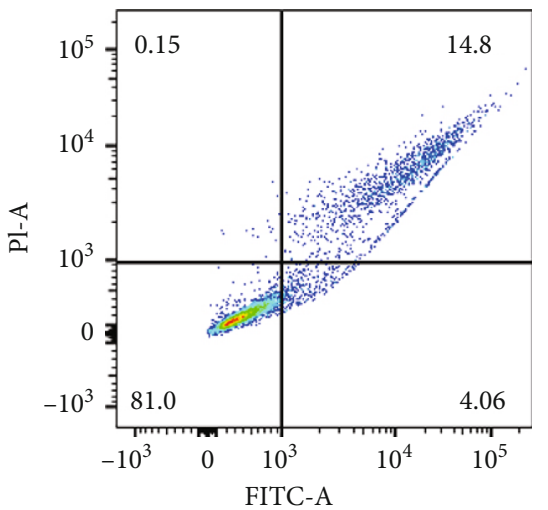

(i) (h)

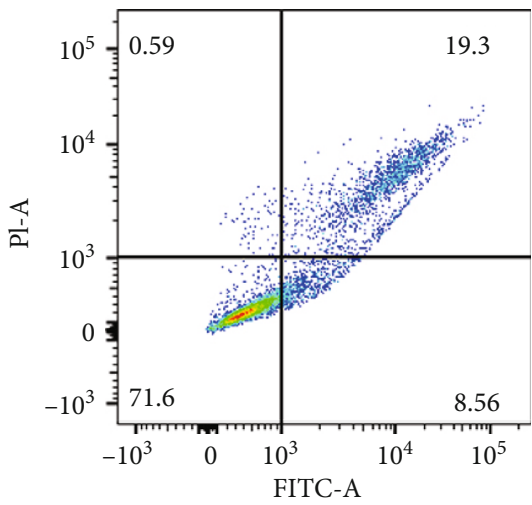

(j)

Figure 2: (a-f) SEM morphologies of MG63 cells cultured the surfaces of ( $a, c, e)$ the GNS Ti samples and (b, d, f) the annealed Ti samples after culturing for 1 day. (g) Proliferation curves of MG63 cells on the GNS Ti and the annealed Ti samples, reflected by measuring OD absorbance values after cultured for $1,3,5$, and 7 days (mean $\pm \mathrm{SD}, n=3,{ }^{*}$ indicates $\left.P<0.05\right)$. (h-j) Flow cytometry results show the MG63 cells apoptosis rate of the blank control group, the GNS Ti group, and the annealed Ti group.

in the annealed $\mathrm{Ti}$ samples, and the average grain size of annealed $\mathrm{Ti}$ was micron-scale in the top surface layer. To evaluate the effectiveness of the nanostructure in vitro, we cultured MG63 cells on the two kinds of Ti samples and subsequently compared cellular behaviours. MG63 cells had the ability of rapid proliferation, strong activity, and unlimited channels. In recent years, they had been widely used in the research of coculture of metal materials and osteoblast-like cells [26]. After 1 day of culture, samples were observed by SEM operated at voltage of $15 \mathrm{kV}$, which showed the 
TABLE 1: Flow cytometry results showing the MG63 cells apoptosis rate of the blank control group, the GNS Ti group, and the annealed Ti group.

\begin{tabular}{lccc}
\hline Cell & Blank control (\%) & GNS Ti (\%) & Annealed Ti (\%) \\
\hline Late apoptotic cells and necrotic cells & $6.76 \pm 2.07$ & $10.38 \pm 3.52^{\Delta}$ & $15.82 \pm 3.30^{*}$ \\
Early apoptotic cells & $3.93 \pm 1.11$ & $4.31 \pm 0.97^{\Delta}$ & $9.83 \pm 3.74^{*}$ \\
Normal cells & $88.03 \pm 2.43$ & $84.54 \pm 3.77^{\Delta}$ & $73.42 \pm 2.49$ \\
\hline
\end{tabular}

Data are presented as mean $\pm \mathrm{SD}, n=3$, and ${ }^{*}$ indicates $P<0.05$, compared with the blank control group. Data are presented as mean $\pm \mathrm{SD}, n=3$, ${ }^{\Delta}$ indicates $P<0.05$, compared with the annealed Ti group.

adhesion and morphology of the MG63 cells. The proliferation behaviour of MG63 cells was analyzed by optical density (OD) absorbance measurements after 1, 3, 5, and 7 days of culture. After 6 days of culture, we analyzed the cell suspensions of each group by flow cytometry to study the effect of materials on cell apoptosis. Cell adhesion, proliferation, and apoptosis have been always important indicators for evaluating osteointegration of implants. Adhesion is usually the initial event after cells come into contact with materials [27]. Bahl et al. reported that the cellular ability to resist the impact of body fluids or blood flow increased with the improving cell adhesion effect in a physiological environment [28]. On the other hand, Logan et al. found that the enhanced adhesion effect of mesenchymal stem cells could promote subsequent cell proliferation and osteogenic differentiation [29]. Therefore, cell adhesion effect was crucial for regulating subsequent cellular behaviours. Wang et al. reported that the main functions of osteoblasts which induced from stem cells were to synthesize bone matrix and promote mineralization of the matrix to form bone tissue [30]. The excellent osteoblast proliferation ability could accelerate the occurrence of osteointegration on the surface of the materials [31]. Yuan et al. reported that osteoblast apoptosis was related to bone reconstruction in multiple parts of the body. Inhibition of osteoblast apoptosis could prolong the survival time of cells and affect osseointegration around orthopedic implants [32]. It was found in this study that the MG63 cells on the GNS Ti spread better and the cells were polygonal with more pseudopods after 1 day of culture. The result suggested that GNS Ti could promote the cell adhesion effect better than the annealed Ti. The OD values of the two groups of materials were statistically different on the $3 \mathrm{rd}$, 5th, and 7 th days $(P<0.05)$. Moreover, the slope of the GNS Ti group was larger than that of the control group, indicating that GNS Ti could promote the cell proliferation better than the control group. The results of flow cytometry demonstrated that the number of viable cells in the GNS Ti group was more than that in the annealed Ti group, while the number of late apoptotic cells in the annealed Ti group were significantly more than that in the GNS Ti group, which showed that the ability of GNS Ti to inhibit cell apoptosis was higher than that of annealed Ti. The above results demonstrated that the nanostructure on the Ti surface might be one of the effective methods to improve cellular behaviours of the osteoblastlike cells.

In order to explore the related mechanism of GNS Ti promoting cellular behaviours, we tested the mineralization ability, protein adsorption, and hydrophilicity of two sets of materials because it has been shown that cellular behaviours might be affected by those properties [33-40]. Lee et al. found that the compound formed by calcium and phosphorus deposition could significantly improve the adhesion and proliferation of bone marrow mesenchymal stem cells [41]. Moreover, Sharkov et al. reported that the osteoblasts were cocoltured with compound formed by calcium and phosphorus deposition, the results of which showed that the compound could obviously upregulate the expression level of osteogenesis-related genes of the cells [42]. So, the increased calcium and phosphorus deposition could promote osteogenic behaviours of cells. The results of biomimetic mineralization experiment in this study demonstrated that the surface of GNS Ti induced the formation of new compounds and formed a spherical coating. The surface of annealed $\mathrm{Ti}$ was snow-like coating and did not induce the formation of new compounds. Furthermore, the EDX analysis showed that those new compounds on the GNS Ti surface mainly contained calcium and phosphorus. Durmus et al. reported that the SMAT metal materials showed excellent hydrogen storage reversibility and promoted surface activation. As the surface activation energy was increasing, the adsorption capacity for calcium and phosphorus ions increased [26]. Venkatsurya et al. found that the surface energy of materials was increased after SMAT, so that the mineralization was promoted [43]. Therefore, the gradient nanostructure obtained after SMAT treatment in this study might improve the surface mineralization ability of materials.

On the other hand, it was well known that the first step for biomaterial after implantation is protein adsorption, and the composition and structure of the material surface determine the amount and type of protein adsorption [44]. The greater the amount of protein adsorbed, the better the adhesion of subsequent cells [45-50]. In this study, it was shown that as the incubation time increased, the amount of protein adsorption of the GNS Ti was always more than that of the annealed Ti. The amount of protein adsorption was statistically different on 1st, 4th, and 24th hours $(P<0.05)$. Especially, the amount of protein adsorption of the GNS Ti materials increased rapidly during 4 hours compared with that of the annealed Ti. So it was indicated that the GNS Ti had better protein adsorption capacity than the annealed $\mathrm{Ti}$ and completed the protein adsorption on the surface in a comparatively short time.

Moreover, the cellular behaviours were closely related to the hydrophilicity of the materials [51]. It was reported that the surface of untreated $\mathrm{Ti}$ implants were generally weakly hydrophilic or even hydrophobic [52]. However, in this 


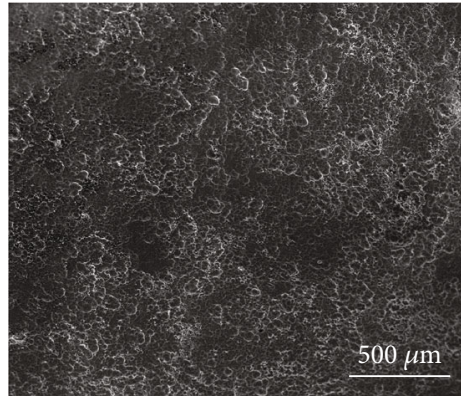

(a)

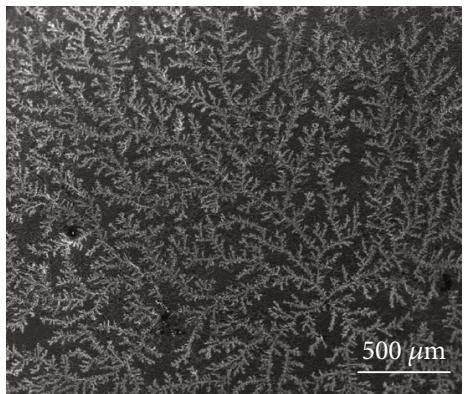

(c)

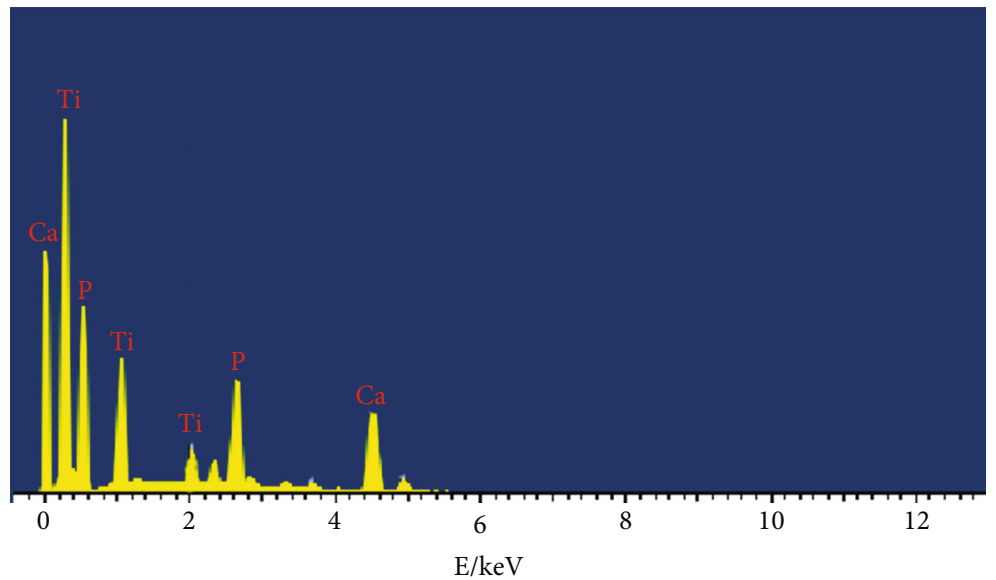

(e)

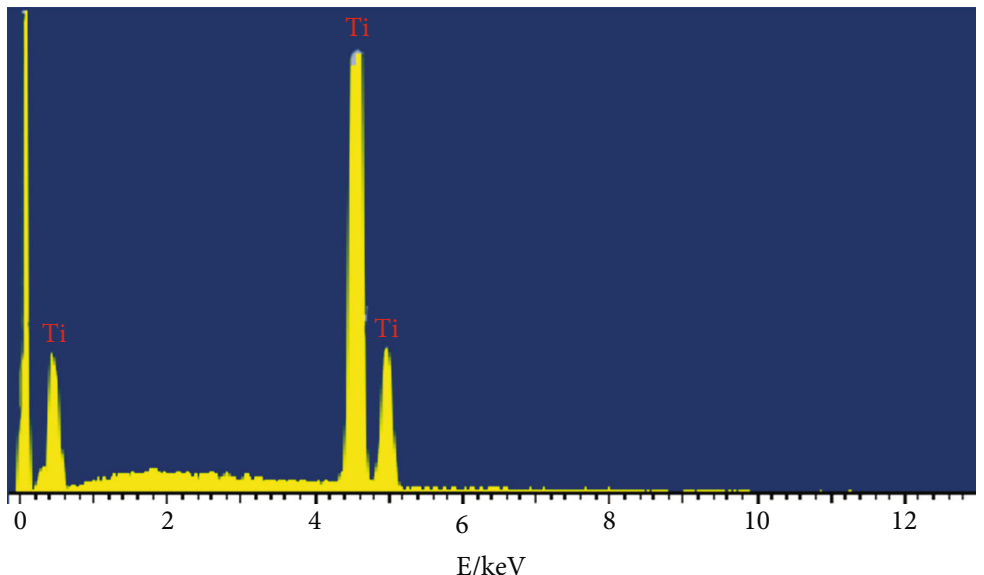

(f)

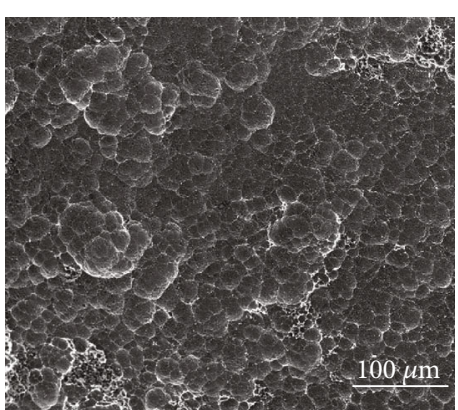

(b)

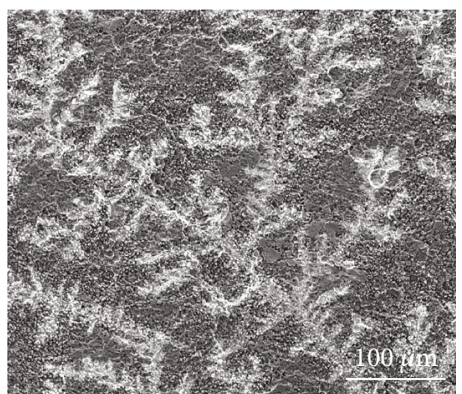

(d)

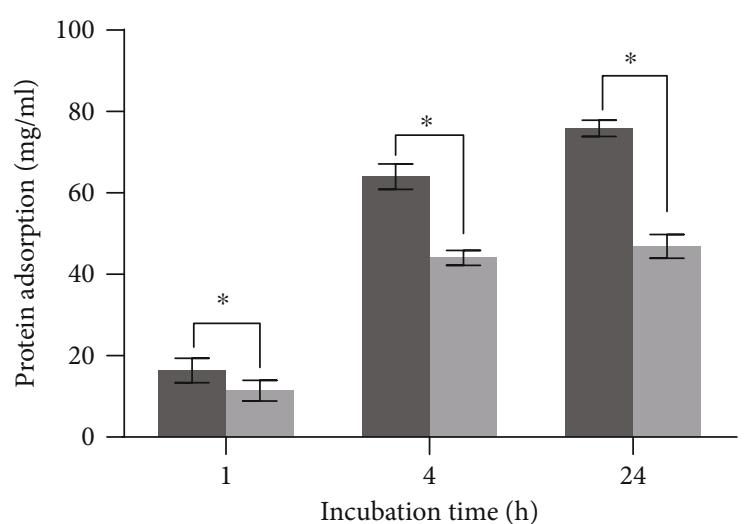

GNS Ti

Annealed Ti

(g)

Figure 3: Continued. 

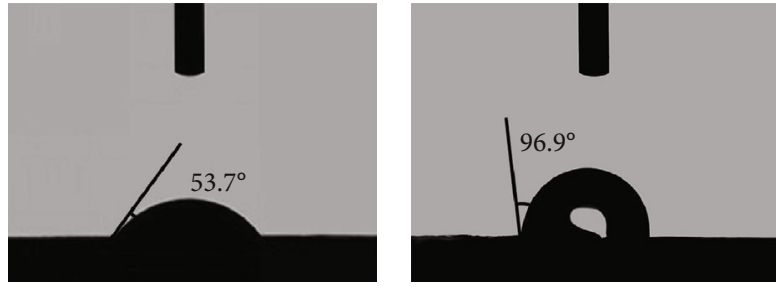

(h)

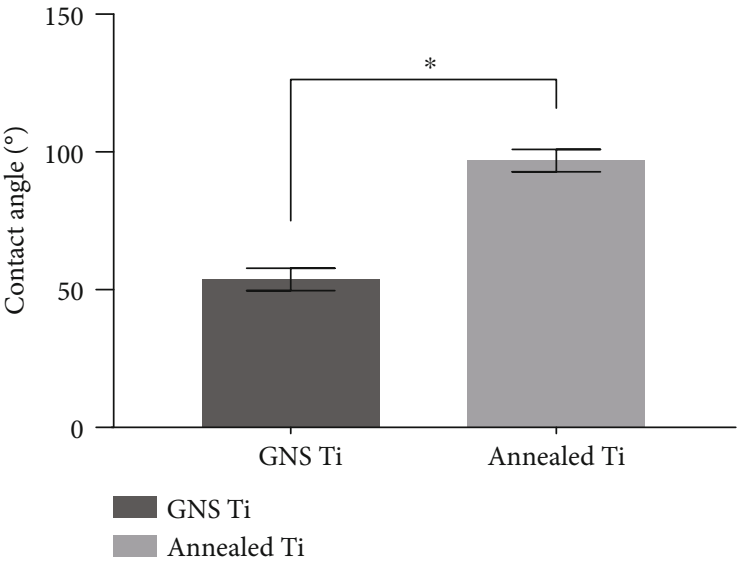

$(\mathrm{j})$

FIGURE 3: (a-d) SEM images show the results of biomimetic mineralization on the surface of $(a, b)$ the GNS Ti samples and (c, d) the annealed Ti samples after immersion in SBF for 28 days. (e, f) EDX analysis performed on the GNS Ti samples and the annealed Ti samples immersed in SBF for 28 days. (g) Protein adsorption results on the GNS Ti samples and the annealed Ti samples immersed in medium containing 10\% fetal bovine serum for 1,4 , and $24 \mathrm{~h}$. (mean $\pm \mathrm{SD}, n=3,{ }^{*}$ indicates $P<0.05$ ). (h-j) Water droplet contact angles of the GNS Ti samples and the annealed Ti samples (mean $\pm \mathrm{SD}, n=3,{ }^{*}$ indicates $P<0.05$ ).

TABLE 2: The protein adsorption results of the GNS Ti and annealed Ti samples at different time points.

\begin{tabular}{lccc}
\hline Time $/ \mathrm{h}$ & 1 & 4 & 24 \\
\hline GNS Ti $(\mu \mathrm{g} / \mathrm{ml})$ & $16.3861 \pm 3.0270^{*}$ & $64.0108 \pm 3.1453^{*}$ & $75.8873 \pm 2.0287^{*}$ \\
Annealed Ti $(\mu \mathrm{g} / \mathrm{ml})$ & $11.4245 \pm 2.5289$ & $54.0222 \pm 1.8226$ & $56.8764 \pm 2.9268$ \\
\hline
\end{tabular}

Data are presented as mean $\pm \mathrm{SD}, n=3,{ }^{*}$ indicates $P<0.05$, compared with the annealed Ti group.

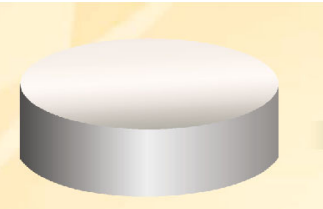

$\mathrm{Ti}$

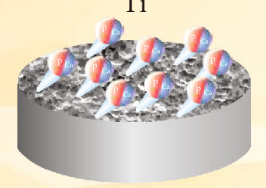

Enhanced mineralization capacity

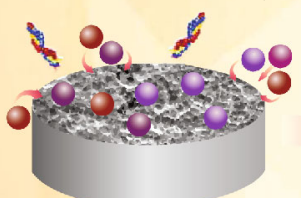

Improved protein adsorption ability

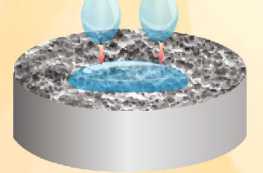

Increased hydrophilicity

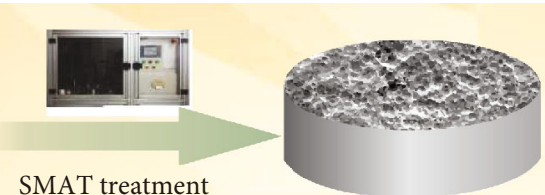

GNS Ti

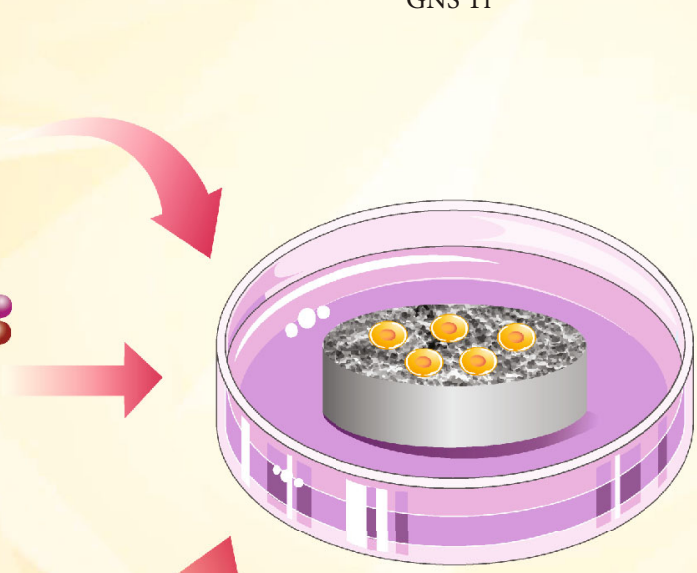

MG63 cells were cocultured with the GNS Ti

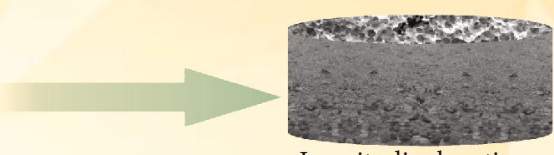

Longitudinal section

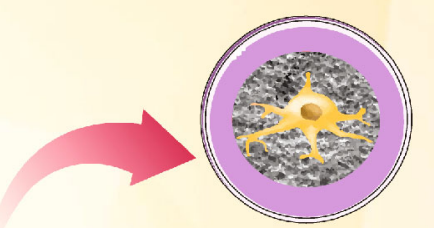

Superior adhesion effect

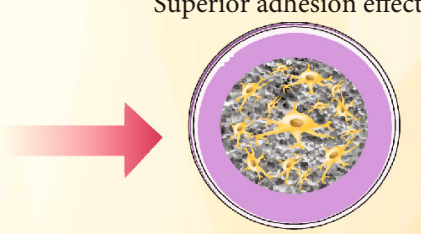

Higher proliferation ability

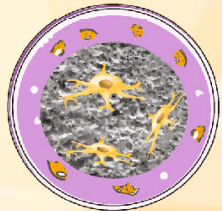

Better anti apoptotic ability

Figure 4: The pattern diagram for the effect of GNS Ti on behaviours of MG63 cells in vitro and its preliminary mechanism. 
study, the results showed that GNS Ti was significantly more hydrophilic than the annealed Ti. Ji et al. reported that the surface of the hydrophilic material could increase the amount of adsorbed protein, thereby promoting the adhesion of osteoblasts and inhibiting cell apoptosis [53]. Li et al. found that the excellent surface hydrophilicity could obtain larger surface energy, promoting the behaviours of human periodontal ligament stem cells [54]. Edalati et al. reported that the surface of the hydrophilic material had a more active biological conformation, which promoted adhesion of MC-3T3 cells [55].

In this study, the enhanced hydrophilicity might be another main reason why the GNS Ti promoted cellular behaviours better.

Above all, this study has demonstrated the effects of GNS Ti on behaviours of MG63 cells in vitro and elucidated its preliminary mechanism, as shown in Figure 4. It provides the theoretical and experimental foundations for the applications of GNS Ti in dental implants. However, the related molecular biology mechanism of GNS Ti remains unclear, and in vivo study is still blank. Before a new material can be used in clinic, it must undergo a lot of comprehensive in vivo and in vitro studies $[56,57]$. In the near future, we will focus on whether GNS Ti can promote osteogenic differentiation of bone-related cells to further examine the osteogenic functions of the GNS Ti. Simultaneously, we will conduct a series of animal experiments to detect whether the material has the problems of metal ion release in the body and evaluate the biocompatibility of the GNS Ti. Furthermore, we will implant GNS Ti into the mandibular defect of animals to examine the formation of the new bone around the material. Hopefully, we can come up with more meaningful and constructive research results soon.

\section{Conclusion}

In this study, GNS Ti was successfully prepared by means of SMAT. In vitro studies into behaviours of the cultured MG63 cells demonstrated that the GNS Ti promoted adhesion effect and proliferation of the cells better than the annealed $\mathrm{Ti}$, while the ability of GNS Ti to inhibit cell apoptosis was better than that of annealed $\mathrm{Ti}$, the preliminary mechanism of which indicated by this study might be the enhanced mineralization capacity, protein adsorption ability, and hydrophilicity of the GNS Ti due to its specific nanostructure that improved the cell behaviours. Although further investigations into the in vivo responses are needed, we believe that the GNS Ti will find broad applications in dental implants and joint replacements.

\section{Data Availability}

The data used to support the findings of this study are available from the corresponding author upon request.

\section{Conflicts of Interest}

The authors declare that there are no conflicts of interest regarding the publication of this paper.

\section{Authors' Contributions}

Xue Luo, Chen Liang, and Ning Li contributed equally to this work.

\section{Acknowledgments}

This study was supported by the National Natural Science Foundation of China (No. 81970980), Liaoning Provincial Key Research Plan Guidance Project (No. 2018225078), Liaoning Provincial Natural Science Foundation Guidance Project (No. 2019-ZD-0749), Liaoning Province, Colleges and Universities Basic Research Project (No. LFWK201717), Central Government of Liaoning Province to Guide Local Science and Technology Development Project (No. 2017108001), Shenyang Major Scientific and Technological Innovation Research and Development Plan (No. 19-112-4027), and the Second Batch of Medical Education Scientific Research Projects of the 13th Five-Year Plan of China Medical University (No. YDJK2018017).

\section{References}

[1] N. Aparna and S. Rajesh, "Tooth-implant connection: a critical review," Journal of Dental Implants, vol. 3, no. 2, pp. 142-147, 2013.

[2] G. E. Abrosimova and A. S. Aronin, "Surface morphology of deformed amorphous-nanocrystalline materials and the formation of nanocrystals," Journal of Surface Investigation: X-Ray, Synchrotron and Neutron Techniques, vol. 12, no. 3, pp. 492-498, 2018.

[3] A. Muthuchamy, M. Rajadurai, A. R. Annamalai, and D. K. Agrawal, "Effect of nickel addition on microstructure and mechanical properties of the spark plasma sintered $\mathrm{Ti}-6 \mathrm{Al}-$ $4 \mathrm{~V}$ alloy," Transactions of the Indian Institute of Metals, vol. 72, no. 8, pp. 2127-2134, 2019.

[4] H. Xing, X. Wang, S. Xiao et al., "Osseointegration of layer-bylayer polyelectrolyte multilayers loaded with IGF1 and coated on titanium implant under osteoporotic condition," International Journal of Nanomedicine, vol. 12, no. 3, pp. 77097720, 2017.

[5] C. C. Novak, A. R. Hsu, C. J. Della Valle et al., "Metal ion levels in maternal and placental blood after metal-on-metal total hip arthroplasty," American Journal of Orthopedics, vol. 43, no. 12, pp. E304-E308, 2014.

[6] A. Deing, T. Ebel, R. Willumeit-Römer, and B. J. C. Luthringer, "Comparison of the influence of phospholipid-coated porous Ti-6Al-4V material on the osteosarcoma cell line Saos-2 and primary human bone derived cells," Metals, vol. 6, no. 3, p. 66, 2016.

[7] A. Hatem, J. Lin, R. Wei et al., "Tribocorrosion behavior of low friction TiSiCN nanocomposite coatings deposited on titanium alloy for biomedical applications," Surface \& Coatings Technology, vol. 347, no. 7, pp. 1-12, 2018.

[8] Q. Yao, J. Sun, G. Zhang, W. Tong, and H. Zhang, "Enhanced toughness of nitrided layers formed on Ti-6Al-4V alloy via surface mechanical attrition pre-treatment," Vacuum, vol. 142, no. 3, pp. 45-51, 2017.

[9] F. Veronesi, G. Giavaresi, M. Fini et al., "Osseointegration is improved by coating titanium implants with a nanostructured thin film with titanium carbide and titanium oxides clustered 
around graphitic carbon," Materials Science and Engineering C, vol. 70, Part 1, pp. 264-271, 2017.

[10] T. J. Webster and J. U. Ejiofor, "Increased osteoblast adhesion on nanophase metals: Ti, Ti6Al4V, and CoCrMo," Biomaterials, vol. 25, no. 19, pp. 4731-4739, 2004.

[11] G. K. Thakral, R. Thakral, N. Sharma, J. Seth, and P. Vashisht, "Nanosurface - the future of implants," Journal of Clinical and Diagnostic Research, vol. 8, no. 5, pp. ZE07-ZE10, 2014.

[12] K. Zhang, Y. Fan, N. Dunne, and X. Li, "Effect of microporosity on scaffolds for bone tissue engineering," Regenerative Biomaterials, vol. 5, no. 2, pp. 115-124, 2018.

[13] L. Bacakova, E. Filova, J. Liskova, I. Kopova, M. Vandrovcova, and J. Havlikova, "Chapter 4 - Nanostructured materials as substrates for the adhesion, growth, and osteogenic differentiation of bone cells," Nanobiomaterials in Hard Tissue Engineering, vol. 4, pp. 103-153, 2016.

[14] Y. Chen, H. Zhao, R. Wang, B. Lan, and L. Deng, "Characterization and evaluation of titanium substrates coated with gelatin/hydroxyapatite composite for culturing rat bone marrow derived mesenchymal stromal cells," Biomedical Engineering: Applications, Basis and Communications, vol. 24, no. 3, pp. 197-206, 2012.

[15] S. P. Yang, H. S. Wen, T. M. Lee, and T. S. Lui, "Cell response on the biomimetic scaffold of silicon nano- and microtopography," Journal of Materials Chemistry B, vol. 4, no. 10, pp. 1891-1897, 2016.

[16] R. Huang, H. Zhuang, and Y. Han, "Second-phase-dependent grain refinement in $\mathrm{Ti}-25 \mathrm{Nb}-3 \mathrm{Mo}-3 \mathrm{Zr}-2 \mathrm{Sn}$ alloy and its enhanced osteoblast response," Materials Science and Engineering: C, vol. 35, no. 7, pp. 144-152, 2014.

[17] X. Li, H. Liu, X. Niu et al., "The use of carbon nanotubes to induce osteogenic differentiation of human adipose-derived MSCs in vitro and ectopic bone formation in vivo," Biomaterials, vol. 33, no. 19, pp. 4818-4827, 2012.

[18] W. Wang, S. Liao, Y. Zhu, M. Liu, Q. Zhao, and Y. Fu, "Recent applications of nanomaterials in prosthodontics," Journal of Nanomaterials, vol. 2015, Article ID 408643, 11 pages, 2015.

[19] X. Wu, N. Tao, Y. Hong et al., "Strain-induced grain refinement of cobalt during surface mechanical attrition treatment," Acta Materialia, vol. 53, no. 3, pp. 681-691, 2005.

[20] W. Wang, Q. Zhao, S. Liao, and Y. Zhu, "Application of stem cells and nanomaterials in prosthodontics," Journal of Nanoscience and Nanotechnology, vol. 16, no. 9, pp. 89358947, 2016.

[21] C. Y. Guo, A. T. H. Tang, and J. P. Matinlinna, "Insights into surface treatment methods of titanium dental implants," Journal of Adhesion Science and Technology, vol. 26, no. 1-3, pp. 189-205, 2012.

[22] X. Li, L. Wang, Y. Fan, Q. Feng, F. Z. Cui, and F. Watari, "Nanostructured scaffolds for bone tissue engineering," Journal of Biomedical Materials Research Part A, vol. 101A, no. 8, pp. 2424-2435, 2013.

[23] X. Li, J. Wei, K. E. Aifantis et al., "Current investigations into magnetic nanoparticles for biomedical applications," Journal of Biomedical Materials Research Part A, vol. 104, no. 5, pp. 1285-1296, 2016.

[24] G. Wang, X. Liu, H. Zreiqat, and C. Ding, "Enhanced effects of nano-scale topography on the bioactivity and osteoblast behaviors of micron rough $\mathrm{ZrO}_{2}$ coatings," Colloids and Surfaces B: Biointerfaces, vol. 86, no. 2, pp. 267-274, 2011.
[25] F. F. Borghi, P. A. Bean, M. D. M. Evans, T. van der Laan, S. Kumar, and K. Ostrikov, "Nanostructured graphene surfaces promote different stages of bone cell differentiation," Nano-Micro Letters, vol. 10, no. 3, p. 47, 2018.

[26] N. G. Durmus and T. J. Webster, "Nanostructured titanium: the ideal material for improving orthopedic implant efficacy?," Nanomedicine, vol. 7, no. 6, pp. 791-793, 2012.

[27] B. B. Shotorbani, E. Alizadeh, R. Salehi, and A. Barzegar, "Adhesion of mesenchymal stem cells to biomimetic polymers: a review," Materials Science and Engineering, vol. 71, no. 4, pp. 1192-1200, 2017.

[28] S. Bahl, B. T. Aleti, S. Suwas, and K. Chatterjee, "Surface nanostructuring of titanium imparts multifunctional properties for orthopedic and cardiovascular applications," Materials \& Design, vol. 144, no. 7, pp. 169-181, 2018.

[29] N. Logan, A. Sherif, A. J. Cross et al., “ $\mathrm{TiO}_{2}$-coated CoCrMo: improving the osteogenic differentiation and adhesion of mesenchymal stem cells in vitro," Journal of Biomedical Materials Research Part A, vol. 103, no. 3, pp. 1208-1217, 2015.

[30] P. Wang, L. Zhao, J. Liu, M. D. Weir, X. Zhou, and H. H. K. Xu, "Bone tissue engineering via nanostructured calcium phosphate biomaterials and stem cells," Bone Research, vol. 2, no. 1, article 14017, 2014.

[31] X. Liu, B. Wang, Y. Sun, Y. Jia, and Z. Xu, “Astragalus root extract inhibits retinal cell apoptosis and repairs damaged retinal neovascularization in retinopathy of prematurity," Cell Cycle, vol. 18, no. 22, pp. 3147-3159, 2019.

[32] Y. Yuan, S. Jin, X. Qi et al., "Osteogenesis stimulation by copper-containing 316 L stainless steel via activation of akt cell signaling pathway and Runx2 upregulation," Journal of Materials Science \& Technology, vol. 35, no. 11, pp. 2727-2733, 2019.

[33] F. Variola, J. B. Brunski, G. Orsini, P. Tambasco de Oliveira, R. Wazen, and A. Nanci, "Nanoscale surface modifications of medically relevant metals: state-of-the art and perspectives," Nanoscale, vol. 3, no. 2, pp. 335-353, 2011.

[34] K. Zhang, X. F. Xiao, X. M. Wang, Y. B. Fan, and X. M. Li, "Topographical patterning: characteristics of current processing techniques, controllable effects on material properties and co-cultured cell fate, updated applications in tissue engineering, and improvement strategies," Journal of Materials Chemistry B, vol. 7, no. 45, pp. 7090-7109, 2019.

[35] L. Wang, S. Wu, G. Cao, Y. Fan, N. Dunne, and X. Li, "Biomechanical studies on biomaterial degradation and co-cultured cells: mechanisms, potential applications, challenges and prospects," Journal of Materials Chemistry B, vol. 7, no. 47, pp. 7439-7459, 2019.

[36] S. Faghihi, D. Li, and J. A. Szpunar, "Tribocorrosion behaviour of nanostructured titanium substrates processed by highpressure torsion," Nanotechnology, vol. 21, no. 48, article 485703, 2010.

[37] B. C. Ward and T. J. Webster, "The effect of nanotopography on calcium and phosphorus deposition on metallic materials in vitro," Biomaterials, vol. 27 , no. 16, pp. 3064-3074, 2006.

[38] C. Wang, G. Cao, T. Zhao et al., "Terminal group modification of carbon nanotubes determines covalently bound osteogenic peptide performance," ACS Biomaterials Science \& Engineering, vol. 6, no. 2, pp. 865-878, 2020.

[39] R. Huang, S. Lu, and Y. Han, "Role of grain size in the regulation of osteoblast response to Ti-25Nb-3Mo-3Zr-2Sn alloy," 
Colloids and Surfaces B: Biointerfaces, vol. 111, no. 1, pp. 232241, 2013.

[40] M. Jamesh, T. S. N. Sankara Narayanan, P. K. Chu, I. S. Park, and M. H. Lee, "Effect of surface mechanical attrition treatment of titanium using alumina balls: surface roughness, contact angle and apatite forming ability," Frontiers of Materials Science, vol. 7, no. 3, pp. 285-294, 2013.

[41] J. H. Lee, S. M. Lee, Y. C. Shin et al., "Spontaneous osteodifferentiation of bone marrow-derived mesenchymal stem cells by hydroxyapatite covered with graphene nanosheets," Journal of Biomaterials and Tissue Engineering, vol. 6, no. 10, pp. 818825, 2016.

[42] E. V. Sharkov, A. V. Chistyakov, V. V. Shchiptsov, M. M. Bogina, and P. V. Frolov, "Origin of Fe-Ti oxide mineralization in the middle Paleoproterozoic Elet'ozero Syenite-Gabbro intrusive complex (Northern Karelia, Russia)," Geology of Ore Deposits, vol. 60, no. 2, pp. 172-200, 2018.

[43] P. K. C. Venkatsurya, W. W. Thein-Han, R. D. K. Misra, M. C. Somani, and L. P. Karjalainen, "Advancing nanograined/ultrafine-grained structures for metal implant technology: interplay between grooving of nano/ultrafine grains and cellular response," Materials Science and Engineering: C, vol. 30, no. 7, pp. 1050-1059, 2010.

[44] S. A. Chamgordani, R. Miresmaeili, and M. Aliofkhazraei, "Improvement in tribological behavior of commercial pure titanium (CP-Ti) by surface mechanical attrition treatment (SMAT)," Tribology International, vol. 119, no. 2, pp. 744752, 2018.

[45] A. Przekora, A. Benko, M. Blazewicz, and G. Ginalska, "Hybrid chitosan/ $\beta$-1,3-glucan matrix of bone scaffold enhances osteoblast adhesion, spreading and proliferation via promotion of serum protein adsorption," Biomedical Materials, vol. 11, no. 4, article 045001, 2016.

[46] S. Khan, A. A. Ansari, C. Rolfo et al., "Evaluation of in vitro cytotoxicity, biocompatibility, and changes in the expression of apoptosis regulatory proteins induced by cerium oxide nanocrystals," Science and Technology of Advanced Materials, vol. 18, no. 1, pp. 364-373, 2017.

[47] G. O. Alrabeah, P. Brett, J. C. Knowles, and H. Petridis, “The effect of metal ions released from different dental implantabutment couples on osteoblast function and secretion of bone resorbing mediators," Journal of Dentistry, vol. 66, pp. 91-101, 2017.

[48] D. De Santis, P. Pancera, U. Luciano et al., "Short-term in vivo evaluation of cellular DNA damage induced by fixed orthodontic appliances," Journal of Biological Regulators and Homeostatic Agents, vol. 32, 2 Supplement 2, pp. 75-80, 2018.

[49] T. A. Bhat, A. K. Chaudhary, S. Kumar et al., "Endoplasmic reticulum-mediated unfolded protein response and mitochondrial apoptosis in cancer," Biochimica et Biophysica Acta Reviews on Cancer, vol. 1867, no. 1, pp. 58-66, 2017.

[50] C. Zhao, W. Ji, P. Han, J. Zhang, Y. Jiang, and X. Zhang, "In vitro and in vivo mineralization and osseointegration of nanostructured $\mathrm{Ti}^{6} \mathrm{Al}_{4} \mathrm{~V}$," Journal of Nanoparticle Research, vol. 13, no. 2, pp. 645-654, 2011.

[51] K. M. Hotchkiss, G. B. Reddy, S. L. Hyzy, Z. Schwartz, B. D. Boyan, and R. Olivares-Navarrete, "Titanium surface characteristics, including topography and wettability, alter macrophage activation," Acta Biomaterialia, vol. 31, no. 3, pp. 425-434, 2016.

[52] I. G. Siller, A. Enders, T. Steinwedel et al., "Real-time live-cell imaging technology enables high-throughput screening to verify in vitro biocompatibility of $3 \mathrm{D}$ printed materials," Materials, vol. 12, no. 13, p. 2125, 2019.

[53] W. P. Ji, P. Han, C. L. Zhao, Y. Jiang, and X. N. Zhang, "Increased osteoblast adhesion on nanophase $\mathrm{Ti}_{6} \mathrm{Al}_{4} \mathrm{~V}$," Science Bulletin, vol. 53, no. 11, pp. 1757-1762, 2008.

[54] Z. Li, J. Qiu, L. Q. du, L. Jia, H. Liu, and S. Ge, “ $\mathrm{TiO}_{2}$ nanorod arrays modified Ti substrates promote the adhesion, proliferation and osteogenic differentiation of human periodontal ligament stem cells," Materials Science and Engineering: C, vol. 76, pp. 684-691, 2017.

[55] K. Edalati, M. Novelli, S. Itano et al., "Effect of gradientstructure versus uniform nanostructure on hydrogen storage of Ti-V-Cr alloys: Investigation using ultrasonic SMAT and HPT processes," Journal of Alloys and Compounds, vol. 737, no. 4, pp. 337-346, 2018.

[56] X. Li, L. Wang, Y. Fan, Q. Feng, and F. Z. Cui, "Biocompatibility and toxicity of nanoparticles and nanotubes," Journal of Nanomaterials, vol. 2012, Article ID 548389, 19 pages, 2012.

[57] Z. Lin, Y. Zhao, P. K. Chu et al., "A functionalized $\mathrm{TiO}_{2} / \mathrm{Mg}_{2}$ $\mathrm{TiO}_{4}$ nano-layer on biodegradable magnesium implant enables superior bone-implant integration and bacterial disinfection," Biomaterials, vol. 219, article 119372, 2019. 